\title{
ELŻBIETA WĘCŁAWOWICZ-BILSKA
}

Instytut Projektowania Miast i Regionów

Wydział Architektury

Politechnika Krakowska im. Tadeusza Kościuszki

\section{WPLYW AKTYWNOŚCI GOSPODARCZEJ NA KSZTAŁT PRZESTRZENI MAŁYCH MIAST W KARPATACH POLSKICH \\ THE INFLUENCE OF ECONOMIC ACTIVITY ON THE SHAPE OF SMALL TOWNS IN POLISH CARPATHIANS MOUNTAINS}

Artykuł wpłynął do redakcji 10.01.2016; po recenzjach zaakceptowany 10.09.2016.

Węcławowicz-Bilska E., 2016, Wptyw aktywności gospodarczej na kształt przestrzeni matych miast w Karpatach Polskich, [w:] Bartosiewicz B. (red.), Tendencje $w$ rozwoju gospodarczym i przestrzennym matych miast $w$ Polsce. Trends in economical and spatial development of small towns in Poland, „Space-Society-Economy”, 17, Institute of the Built Environment and Spatial Policy, Wydawnictwo Uniwersytetu Łódzkiego, Łódź, s. 85-99.

Prof. dr hab. inż. arch. Elżbieta Węcławowicz-Bilska, Instytut Projektowania Miast i Regionów, Wydziat Architektury, Politechnika Krakowska im. Tadeusza Kościuszki, ul. Warszawska 24, 31-155 Kraków

e-mail: eweclaw@poczta.onet.pl

\section{Zarys treści}

Region karpacki charakteryzuje nagromadzenie licznych zasobów środowiska przyrodniczego i kulturowego chronionych prawnie. Historyczną, tradycyjną funkcją tych obszarów było rolnictwo i pasterstwo. Zasoby naturalnych surowców leczniczych są podstawą rozwoju lecznictwa uzdrowiskowego. Przeprowadzenie linii kolejowych w II połowie XIX wieku zdynamizowało rozwój gospodarczy oparty na przemyśle oraz turystyce i wypoczynku. Kolejne działania przyczyniły się i nadal powodują zwiększenie powierzchni zurbanizowanej, często w sposób nieuporządkowany przestrzennie. Konsekwencje krajobrazowe, estetyczne, społeczne, a także w końcu gospodarcze tych decyzji mogą mieć długotrwały wpływ na ład przestrzenny oraz możliwości trwałego i zrównoważonego rozwoju.

\section{Slowa kluczowe}

Region karpacki, małe miasta, rozwój gospodarczy. 


\subsection{WPROWADZENIE}

Region karpacki zajmuje jedynie 3\% powierzchni kraju. Duże obszary Karpat Polskich objęto rożnymi formami ochrony wartości środowiska przyrodniczego i krajobrazu. Liczne historyczne małe miasteczka o zachowanym historycznym rozplanowaniu, z tradycyjną zabudową, podlegają ochronie konserwatorskiej, podobnie jak założenia pałacowo-parkowe lub parkowo-dworskie, zamki obronne lub ich ruiny, pojedyncze obiekty i założenia sakralne i inne. Zasoby naturalnych surowców leczniczych są podstawą funkcjonowania tu 12 uzdrowisk statutowych i rozwoju funkcji lecznictwa uzdrowiskowego w kilku kolejnych miejscowościach.

Rejestrowane od II połowy XIX wieku do czasów współczesnych zmiany kształtu przestrzeni małych miast karpackich w dużej mierze wynikały z rozwoju działalności gospodarczej. Największe z nich zostały wywołane wprowadzeniem linii kolejowych w II połowie XIX wieku, co dotyczyło zmiany roli i znaczenia poszczególnych miast w strukturze osadniczej, a w samych miastach nastąpił rozwój terenów przemysłowych w ich sąsiedztwie. Podjęto działania mające na celu zbliżenie ośrodka do linii kolejowej. Gdzie indziej, dzięki zwiększeniu i dostępności rozpoczęto rozwój funkcji wypoczynku, turystyki i lecznictwa uzdrowiskowego.

Rejestrowane już od lat powojennych zmiany w przestrzeni małych miasteczek karpackich wynikały z rozbudowy istniejących zespołów przemysłowych lub lokalizacji nowych oraz wprowadzaniu w przestrzeń miejską zespołów zabudowy mieszkaniowej wielo- $i$ jednorodzinnej $w$ formie osiedli o charakterze wielkomiejskim. Działania te przyczyniły się do niszczenia i zagrażają zachowaniu wartościowego krajobrazu.

W ostatnich latach coraz częściej samorządy lokalne upatrują rozwój gospodarczy gmin w aktywizacji funkcji przemysłu, zwłaszcza w postaci specjalnych stref przemysłowych. Dla poprawy obsługi ludności wznoszone są wielkopowierzchniowe obiekty handlowe. Lokalizacje takich terenów wynikają często z intencji inwestorów, a nie pragmatycznych zasad rozbudowy przestrzennej ośrodka.

$\mathrm{Z}$ kolei rozwój regionu karpackiego w wielu dokumentach planistycznych o charakterze ogólnokrajowym ${ }^{1}$ i regionalnym przewidywany jest na podstawie intensyfikacji funkcji turystyki, wypoczynku i lecznictwa uzdrowiskowego.

Obserwuje się więc konflikt pomiędzy deklaracjami na szczeblu rządowym i regionalnym z zamierzeniami i decyzjami samorządów lokalnych. Konsekwen-

\footnotetext{
${ }^{1}$ Koncepcja przestrzennego zagospodarowania kraju z 2001 roku, Ekspercki projekt koncepcji przestrzennego zagospodarowania kraju do roku 2033, Warszawa, grudzień 2008 r., s. 85. Dokumenty Euroregionu karpackiego - Polska np. Międzynarodowa Konferencja Euroregionu Karpackiego, Arłamów, 20-28.05.2008. Patrz też Koncepcja przestrzennego zagospodarowania kraju 2030 przyjęta na posiedzeniu Rady Ministrów w czerwcu 2011 roku.
} 
cje przestrzenne, społeczne, a także w końcu gospodarcze tych decyzji mogą mieć długotrwały wpływ na ład przestrzenny, istniejące środowisko przyrodniczo-kulturowe regionu karpackiego oraz możliwości jego trwałego i zrównoważonego rozwoju.

Celem artykułu jest przedstawienie zakresu zmian, jakie nastąpiły i nadal postępują w niewielkich ośrodkach miejskich w Karpatach pod wpływem aktywizacji gospodarczej na tle przekształceń, jakie następowały tu od drugiej połowy XIX wieku.

W terenach górskich percepcja kształtu przestrzeni całego założenia miejskiego z tras widokowych prowadzonych w szczytowych rejonach wzgórz i wzniesień jest jednoczesna i wielopłaszczyznowa. Stąd przypadkowa lokalizacja terenów związanych z rozwojem gospodarczym może przyczynić się do obniżenia jakości estetycznej, jak i funkcjonalnej tych miejscowości. Podstawą dociekań przedstawionych $\mathrm{w}$ niniejszym artykule są badania terenowe prowadzone w wybranych małych i średniej wielkości miastach karpackich ${ }^{2}$ w latach 2005-2014.

Prace dotyczące zmian kształtu przestrzeni małych miast tradycyjnych w terenach górskich były prowadzone przez różnych specjalistów. Problem zachowania tożsamości kulturowej i kształtu przestrzennego małych miast, w związku ze zniszczeniami podczas I i II wojny światowej i związana z tym konieczność ich odbudowy, był podejmowany w pracach projektowych i teoretycznych bezpośrednio po odzyskaniu niepodległości (np. Gałęzowski 1916; Drexler 1921). Zwracano też uwagę na stan zachowania i możliwości rozwoju niewielkich, zwłaszcza zabytkowych ośrodków miejskich (np. Wejchert 1947; Dziewoński 1957; Adamczewska-Wejchert 1977; Gzell 1981) podkreślając konieczność dostosowania skali, artykulacji oraz podziałów elewacji nowych budynków mieszkaniowych do form zabudowy tradycyjnej, krytykując wprowadzaną zunifikowaną zabudowę osiedlową. Podejmowano próby reaktywowania tradycyjnej formy małomiasteczkowej o nowej funkcji (Pieńkowska 1971).Współczesne badania W większym stopniu uwzględniają spojrzenia holistyczne (Gzell 1987; Bagiński 1998; Bartkowicz 1999; Zaniewska 2014).

Od kilkudziesięciu lat badania dotyczące rożnych aspektów rozwoju przestrzennego małych miast, głównie w obszarze Polski południowo-wschodniej, są prowadzone w Instytucie Projektowania Miast i Regionów Wydziału Architektury Politechniki Krakowskiej (np. Bartkowicz 1999; Węcławowicz-Bilska 2006 i in.).

\footnotetext{
${ }^{2} \mathrm{Za}$ małe miasteczko autorka uważa jednostki osadnicze liczące nie więcej niż 10 tys. mieszkańców, posiadające charakterystyczne założenie miejskie, niezależnie od ich statutu administracyjnego, a spośród badanych miast tej wielkości żadne nie przekraczało liczby 30 tys. mieszkańców. Wszystkie badane miejscowości są położone w Polsce w obszarze nasunięcia karpackiego adekwatnie do obszaru wyznaczonego (Warszyńska 1995).
} 
Od kilkunastu lat wyniki badań różnych specjalistów dotyczące podstaw rozwoju małych ośrodków miejskich, także w obszarze karpackim, są prezentowane w licznych monografiach pod redakcją T. Marszała (np. 2009ab) i K. Heffnera (Hefner, Marszał 2005). Badania społeczności miast Małopolski od lat prowadzi A. Kwiatek-Sołtys (np. 2004).

\subsection{TRADYCYJNE WARTOŚCI ŚRODOWISKA MALOMIASTECZKOWEGO KARPAT}

Małe miasteczka w obszarze karpackim, lokowane w większości w średniowie$\mathrm{czu}^{3} \mathrm{w}$ miejscu wcześniejszych osad, są do dzisiaj charakterystycznym elementem podgórskiego i górskiego pejzażu. Te niewielkie założenie urbanistyczne silnie powiązane $\mathrm{z}$ otaczającym krajobrazem systemem dróg polnych, ciągami widokowymi z wewnątrz i z zewnątrz miasta, tworzą zwarty zespół krajobrazowo-miejski.

Obecnie w Karpatach Polskich znajduje się ponad 50 miast i ponad 1700 wsi o bardzo zróżnicowanej liczbie ludności ${ }^{4}$. Główna sieć osadnicza jest silnie związana $\mathrm{z}$ ukształtowaniem terenu. Równoleżnikowemu przebiegowi pasm górskich, wznoszących się ku południu, towarzyszą kolejne układy urbanizacji. Najbardziej na północ, na pograniczu nasunięcia karpackiego, występują tereny silnie zurbanizowane związane z obszarem metropolitalnym Krakowa oraz aglomeracjami Tarnowa i Rzeszowa.

U podnóża Beskidów coraz wyraźniej krystalizuje się równoległe śródkarpackie pasmo urbanizacji, które wyznaczają głównie miasta średniej wielkości, takie jak np.: Kęty, Wadowice, Myślenice, Limanowa, Nowy Sącz, Gorlice, Jasło, Krosno, Sanok i Przemyśl wraz z towarzyszącymi im małymi miastami, takimi jak: Sucha Beskidzka, Lanckorona, Dobczyce, Gdów, Brzostek, Kołaczyce, Pilzno i inne. Bardziej na południe rozciągają się tereny tradycyjnie wypoczynkowe $\mathrm{z}$ uzdrowiskami ${ }^{5}$ oraz miejscowościami letniskowymi. Założenia te najczęściej związane są z miastami małymi i średniej wielkości oraz wioskami.

${ }^{3}$ Lata lokacji niektórych miasteczek karpackich, np. Brzostek (1394), Dobczyce (1310), Dukla (1370/1373), Jaśliska (około 1366), Lanckorona (1366), Kołaczyce (1339), Muszyna (1356), Pilzno (1354), Tuchów (1340), Rymanów (1376), Wojnicz (1278), Zator (1292).

${ }^{4}$ Największym miastem jest tu Bielsko-Biała liczące obecnie 175 tys. mieszkańców, najmniejsze nie osiągają 2 tys. osób. Największa wieś liczy prawie 10000 mieszkańców (Kozy k. Bielska-Białej), a najmniejsze wioski we wschodniej części regionu - niespełna 100 osób (np. Smerek w Bieszczadach).

${ }^{5}$ Liczne statutowe uzdrowiska skoncentrowane są w rejonie doliny Popradu - Krynica, Muszyna, Żegiestów, Piwniczna, w Gorcach - Rabka, w Pieninach - Szczawnica, a w Beskidzie Śląskim znajduje się Ustroń, w Beskidzie Niskim - Wysowa, Iwonicz Zdrój, Rymanów-Zdrój, w Bieszczadach - Polańczyk. 
W krajobrazie te niewielkie miejscowości i powiązane widokowo z nimi zamki i założenia parkowo-dworskie, często lokowane na stokach, czasami na wzniesieniach nad dolinami rzek pełnią istotną rolę podkreślającą symbiozę dwóch środowisk - naturalnego i kulturowego. Malowniczości krajobrazu dodają: uprawy polowe na łagodnych zboczach i w dolinach rzek, łąki i pastwiska na bardziej stromych stokach, podzielone widocznymi pasmami zadrzewień, tworzących obudowę biologiczną w dolinach potoków i rzek, łączących się z kompleksami leśnymi obejmującymi górne partie większości grzbietów górskich. Zasoby środowiska przyrodniczego i walory krajobrazu objęte są zróżnicowanym systemem wielkopowierzchniowych form ochrony ${ }^{6}$. W całych Karpatach obserwuje się zróżnicowaną, ale wysoką lesistość terenu, która przekracza średnio $40 \%{ }^{7}$.

W odbiorze krajobrazowo-estetycznym małych miejscowości położonych w obszarach górskich, znakomitą rolę odgrywa środowisko przyrodnicze ingerujące bezpośrednio w przestrzeń miasta, np. stromymi zalesionymi stokami zamykającymi widokowo ulice czy poprzez szerokie panoramy rolniczego krajobrazu widoczne z wyżej położonych partii miejscowości. Konfiguracja terenu umożliwia jednoczesną i wielopłaszczyznową percepcję elementów kulturowych, w tym całościowego obrazu małego miasta ${ }^{8}$.

\subsection{ZMIANY ŚRODOWISKA I KSZTALTU PRZESTRZENI MALOMIASTECZKOWEJ W KARPATACH W KOŃCU XIX WIEKU I W I POLOWIE XX WIEKU}

Budowa linii kolejowych w II połowie XIX wieku, których przebieg odegrał istotne znaczenie w rozwoju gospodarczym poszczególnych miejscowości ${ }^{9}$,

${ }^{6}$ Znajdują się tu 3 międzynarodowe rezerwaty biosfery, 6 parków narodowych, 8 parków krajobrazowych, obszary chronionego krajobrazu oraz ponad 80 rezerwatów przyrody. Łączna ich powierzchnia w Małopolsce wynosi 790348,6 ha, co stanowi 52,1\% jej powierzchni, a na terenie Podkarpacia około 797639 ha, co stanowi 44,5\% jego powierzchni, przy średnim krajowym wskaźniku 32,1\% (http://www.krakow.pios.gov.pl, http://monitoruj.podkarpackie.pl/).

${ }^{7}$ Całkowita lesistość terenu Karpat wynosi 41,4\%, ale jest zróżnicowana. Najmniej lasów występuje na Podhalu - 18,2\%, najwięcej w Tatrach - 73,5\%.Wszystkie lasy górskie objęte są ochroną jako lasy wodochronne.

${ }^{8}$ Sytuacje znane ze starych sztychów czy rysunków, a do dzisiaj spotykane w miejscowościach o ograniczonym rozwoju gospodarczym i chronionych, jak np. Szczepanów, Ciężkowice, Jaśliska, Lanckorona.

${ }^{9}$ CK Galicyjska Kolej Transwersalna z roku 1884 przebiegała z zachodu na wschód przez górskie obszary Karpat, równolegle do oddanej w 1851 roku drogi nr 28. Długość linii kolejowej wyniosła około 800 km. Stacjami końcowymi były Czadca i Husiatyń, a główne dworce kolejowe znajdowały się m.in. w Żywcu, Suchej Beskidzkiej, Jaśle, 
był przyczyną zmian w zagospodarowaniu regionu. Przy liniach kolejowych powstawały dla ich obsługi rozmaite obiekty i urządzenia, które zajmowały duże tereny. Znajdowały się tam lokomotywownie, zakłady obsługi i naprawy taboru, osiedla kolejowe dla pracowników, a także inne zakłady przemysłowe. Kolej aktywizowała życie gospodarcze, stąd w jej sąsiedztwie rozpoczęto lokalizację zakładów przemysłowych ${ }^{10}$, w pobliżu których powstawały osiedla robotnicze i kolejowe.

Wzdłuż realizowanych linii kolejowych, takich jak np. Galicyjska Kolej Transwersalna, Węgiersko-Galicyjska Kolej Żelazna czy Kolej Miast Śląskich i Galicyjskich ${ }^{11}$, w miastach lub nieopodal nich powstawały przystanki kolejowe. Gdy były one znacznie oddalone od centrum miejscowości, wyznaczano i zakładano atrakcyjne aleje łączące miasto $\mathrm{z}$ koleją. Z czasem zyskiwały ważną rolę w mieście z uwagi na sytuowanie wzdłuż nich ważnych budowli publicznych. Dla podkreślenia znaczenia nowego środka transportu w wielu miastach wznoszono reprezentacyjne budynki dworcowe ${ }^{12}$.

W tym czasie w wielu miejscowościach Karpat rozpoczęto także budowę budynków użyteczności publicznej, m.in. związanych z powołaniem starostw,

Krośnie, Sanoku, Zagórzu, Drohobyczu, Stryju i Stanisławowie. Wcześniej, w 1872 roku oddano linię kolejową do Zagórza, a dwa lata później powstała Pierwsza Węgiersko-Galicyjska Kolej Żelazna z Przemyśla - przez Zagórz - do Budapesztu.

${ }^{10} \mathrm{Na}$ przykład rozbudowa ważnego węzła kolejowego w Zagórzu spowodowała zwiększenie zatrudnienia w obsłudze do ok. 3000 kolejarzy, dla których wzniesiono osiedle. Doprowadzona w 1889 roku linia kolejowa do Kalwarii Zebrzydowskiej miała wpływ na powstanie tu w roku 1890 Krajowej Szkoły Stolarstwa, a w 1899 roku pierwszej Parowej Fabryki Mebli S. Łojka (za: serwis internetowy gminy).

Do Alwerni linia kolejowa dodarła z końcem XIX wieku, a na przełomie lat 1923/24 założono tu fabrykę chemiczną. Największy rozwój gospodarczy nastąpił w Gorlicach i Gliniku Marianpolskim, z uwagi na rozwój przemysłu naftowego. Pod koniec XIX wieku znajdowało się tu kilka zakładów przemysłowych, a w 1883 roku inwestorzy anglosascy H.W. Mac Garvey oraz J.S. Bergheim wybudowali fabrykę sprzętu wiertniczego, a po dwóch latach rafinerię ropy naftowej. Były tu też: odlewnia żeliwa i metali kolorowych, fabryki kwasu siarkowego, świec parafinowych, nawozów sztucznych, kotłów i inne.

${ }^{11}$ M. Moczulski (2007, s. 5).

${ }^{12}$ Reprezentacyjne dworce znajdowały się w Tarnowie i Przemyślu. W pozostałych miejscowościach budowano dworce kolejowe zgodnie $\mathrm{z}$ opracowanym wzorcem, jako budynki dwukondygnacyjne z wysuniętymi ryzalitami na osi i dachami naczółkowymi. W wersji skromnej elewacje od strony miasta i peronów były trzy- lub pięcioosiowe, a w większych ośrodkach nawet dziewięcio- czy jedenastoosiowe i trzykondygnacyjne, jak np. dworzec w Nowym Zagórzu po przebudowie w 1917 roku. 
szkół elementarnych ${ }^{13}$, a na początku XX wieku także gimnazjów ${ }^{14}$. Te działania $\mathrm{z}$ jednej strony spowodowały zmianę kierunku naturalnego rozwoju układu przestrzennego miasta oraz zwiększenie jego powierzchni zurbanizowanej, z drugiej zaś strony oddziaływały na skład społeczny mieszkańców, gdyż wraz z rozwojem przemysłu zaczęli pojawiać się robotnicy.

W powiększających swój dobrobyt i liczbę ludności miejscowościach zaczęły pojawiać się, wznoszone $\mathrm{w}$ miejscu drewnianych, murowane świątynie katolickie projektu znanych twórców, zwłaszcza z Politechniki Lwowskiej i ośrodka krakowskiego ${ }^{15}$. Kościoły te w stylu neogotyckim czy secesyjnym stanowiły wyraźne, nowe dominanty w przestrzeni wsi oraz małych i średniej wielkości miast.

Pojawiały się tu nowe okazałe budowle, także siedziby różnych organizacji, jak np. Towarzystwa Gimnastycznego „Sokół”16 czy ochotniczych straży pożarnych, które czasami zachowały się do dziś, np. w Myślenicach.

Okres drugiej połowy XIX wieku i początki wieku XX były czasem kreowania nowych ośrodków o funkcji wypoczynku i lecznictwa uzdrowiskowego. Niektóre powstawały w sąsiedztwie już istniejących miejscowości, jak np. Muszyna, Rabka, Szczawnica, Piwniczna. Inne zakładano w pobliżu źródeł wód mineralnych, jak Rymanów Zdrój i Żegiestów. Nieliczne rozwijano w istniejących ośrodkach, jak np. Iwonicz czy Krynica ${ }^{17}$. Utworzenie, oprócz uzdrowisk, także stacji klimatycznych i letnisk, rozpoczął okres kontynuowany w czasie II Rzeczpospolitej stale rozwijanych funkcji wypoczynku, turystyki i lecznictwa uzdrowiskowego w Karpatach. W konsekwencji w wielu miejscowościach powstawały duże obiekty lecznicze i sanatoryjne prezentujące najnowsze trendy architektoniczne, projektowane przez znakomitych twórców ${ }^{18}$.

${ }^{13} \mathrm{~W}$ związku z reformą edukacyjną w latach 70. XIX wieku wznoszono duże budynki szkół, np. w Myślenicach, Dobczycach, Grybowie - od 1879 roku. Początkowo nauka odbywała się w istniejących obiektach, a np. w Stróżach od 1901 roku w budynku dworca kolejowego, a gimnazjum w budynku Sokoła.

${ }^{14} \mathrm{Na}$ przykład w 1908 roku w Myślenicach z inicjatywy S. Pardyaka powstało jedyne gimnazjum na tym terenie.

${ }^{15}$ Byli to tacy architekci, jak: Jan Sas-Zubrzycki, autor m.in. kościołów w Błażowej (1900), Ciężkowicach (1903), Czortkowie (1918), Jedliczach (1925), Jordanowie (1913), Szczurowej (1893), Kasince Małej (1913); Zdzisław Mączeński - projektant kościołów w Limanowej (1909), Kąclowej (1926), Poroninie (1920), w Wysowej (1936), czy Sławomir Odrzywolski - w Rabce (1902) i Lubniu, a także inni.

${ }^{16} \mathrm{~Np}$. w 1892 roku w Gorlicach miał miejsce pierwszy pokaz kinowy, właśnie w budynku Sokoła.

${ }^{17}$ Okres rozkwitu uzdrowisk karpackich związany był z aktywną działalnością profesora Józefa Dietla.

${ }^{18}$ Na przykład w Krynicy Nowe Lazienki Mineralne W. Klimczaka, pensjonat Patria B. Pniewskiego i tamże Nowy Dom Zdrojowy proj. W. Minkiewicz, w Żegiestowie Nowy 
Zmiany w strukturze osadnictwa i kształcie przestrzeni małych ośrodków osadniczych w Karpatach w okresie II Rzeczpospolitej dotyczyły rozwoju funkcji istniejących. Obserwowane są tu także inwestycje o charakterze strategicznym, związane $\mathrm{z}$ budową tras komunikacyjnych ${ }^{19}$ oraz gospodarką wodną i energetyczną ${ }^{20}$.

\subsection{ZMIANY ŚRODOWISKA I KSZTALTU PRZESTRZENI MALOMIASTECZKOWEJ W KARPATACH W II POLOWIE XX WIEKU}

Transformacja systemu gospodarowania po II wojnie światowej, w głównej mierze dotyczyła zmian w przestrzeni większych miast. Małe ośrodki pozostawały jakiś czas na uboczu wielkich przemian.

Dopiero od lat 60. XX wieku można obserwować większe przekształcenia $\mathrm{w}$ obszarze małych miast. Były one związane z jednej strony ze zmianą systemu gospodarowania $\mathrm{w}$ rolnictwie ${ }^{21}$ (tworzenie PGR-ów i lokowanie w sąsiedztwie miasteczek terenów zabudowy mieszkaniowej w formie wielkomiejskich osiedli) oraz rozbudową istniejących w tych ośrodkach zakładów przemysłowych, zagospodarowaniem terenów składowych i dla obsługi rolnictwa, systemów komunikacyjnych itp., co w istotny sposób powiększyło powierzchnię zurbanizowaną.

Zjawiska te nasiliły się jeszcze bardziej w latach 70., kiedy to w wielu małych miastach powstawały zespoły zabudowy mieszkaniowej w formie osiedli o charakterze wielkomiejskim oraz rozproszone zespoły zabudowy jednorodzinnej i letniskowej, czego konsekwencją było niszczenie wartościowego krajobrazu.

Zespoły mieszkaniowe bloków powstawały często w bezpośrednim sąsiedztwie założeń historycznych i zabytkowych, nierzadko zajmując eksponowane z wnętrza miejscowości południowe stoki wzniesień. Osiedla takie wznoszono nie tylko w ośrodkach, w których rozwijano działalność przemysłową i gospodarczą, np. w Dobczycach, Tymbarku, Kalwarii Zebrzydowskiej, Rymanowie, Wieliczce, Suchej Beskidzkiej, ale także w miejscowościach uzdrowiskowych i letniskowych, np. w Muszynie, Piwnicznej, Rabce, Szczawnicy czy Krynicy. Pięciokondygnacyjne bloki mieszkaniowe, w stosunku do dominujących w miej-

Dom Zdrojowy proj. A. Szyszko-Bogusz i sanatorium Wiktor J. Bagińskiego i Z. Wardzały, w Rymanowie Zdroju w 1928 roku sanatorium „Gozdawa” (za: Węclawowicz-Bilska, 1990).

${ }^{19} \mathrm{Na}$ przykład budowa w połowie lat 30. drogi Kraków-Zakopane.

${ }^{20}$ Regulacja rzek i potoków, budowa sztucznych zbiorników wodnych i elektrowni wodnych, np. w latach 1928-1937 Porąbka na Sole, rozpoczęcie w 1935 roku budowy zapory i elektrowni wodnej w Rożnowie.

${ }^{21}$ Co było związane z tworzeniem PGR-ów i budową dla ich pracowników zespołów mieszkaniowych opartych na miejskich wzorcach, jak np. PGR w Dukli pod Cergową. 
scowościach budynków dwukondygnacyjnych, zmieniały skalę i gabaryt istniejącej zabudowy, zaburzyły ład przestrzenny i spowodowały nadmierną urbanizację tych niewielkich ośrodków. Największe zmiany nastąpiły w Ustroniu, w sąsiedztwie którego założono nowe, duże uzdrowisko w bezpośrednim sąsiedztwie historycznego miasta. W miejscowościach takich powstawały dwa jakby odrębne światy zarówno estetyczne, jak i społeczne.

W latach 70. XX wieku w wielu małych miasteczkach karpackich zaczęły pojawiać się w sąsiedztwie miejscowości różnej wielkości tereny indywidualnej zabudowy mieszkalnej jednorodzinnej, lokalizowanej na eksponowanych stokach. Zabudowa ta realizowana $\mathrm{w}$ konwencji modernistycznej otwartych przestrzeni, o układzie szachownicowym powodowała nadmierne rozciąganie i rozpraszanie miejscowości.

Jednocześnie $\mathrm{w}$ wielu uzdrowiskach wzniesiono wielkokubaturowe sanatoria i zakłady przyrodolecznicze o skali i formie odmiennej od dominującej w tego typu założeniach, zmieniając relacje przestrzenne w tych miejscowościach ${ }^{22}$.

Dla obsługi wzrastającej liczby mieszkańców, a w uzdrowiskach kuracjuszy rozpoczęto budowę pawilonów handlowych, często lokalizowanych w pierzejach rynkowych lub w sąsiedztwie centrum miejskiego. Obiekty te jakkolwiek nie przekraczały gabarytu wysokościowego pobliskiej zabudowy o drobnej skali istniejących, tradycyjnych obiektów budynków z pionową, gęstą artykulacją, to jednak stanowiły horyzontalne dominanty.

\subsection{OBSERWOWANE ZMIANY I ZAGROŻENIA KSZTAŁTU PRZESTRZENI MALYCH MIASTECZEK W POCZĄTKACH XXI WIEKU}

Współcześnie obserwowane tendencje przekształceń niewielkich ośrodków miejskich oparte są na aktywizacji rozwoju gospodarczego polegającego nie tylko na rozwoju przemysłu lokalnego, ale także tworzeniu obszarów uprzywilejowanych dla inwestorów spoza regionu. Dotyczy też rozwoju usług i jest związany przede wszystkim ze wznoszeniem wielkopowierzchniowych obiektów przemysłowych i handlowych. Ich usytuowanie wynika z możliwości lokalizacyjnych na działkach gminnych, intencji inwestorów i dobrej dostępności z tras tranzytowych. $\mathrm{W}$ wielu gminach, zwłaszcza położonych w sąsiedztwie wielkich miast, udostępniane są tereny dla zorganizowanej zabudowy mieszkaniowej charakterystycznej dla miast dużych.

\footnotetext{
${ }^{22} \mathrm{Na}$ przykład kilkunastokondygnacyjne sanatorium Hutnik w Szczawnicy, Continental w Krynicy, czy także bardziej typowe sanatoria w Szczawnicy, Iwoniczu-Zdroju, Rymanowie i innych (Węcławowicz-Bilska, op. cit.).
} 
Coraz większe znaczenie w rozwoju gospodarczym miast średnich i małych w regionie Karpat odgrywają inwestycje związane z realizacjami na ich terenach specjalnych stref ekonomicznych (SSE) lub stref aktywności gospodarczej (SAG), które pojawiają się w coraz większej liczbie karpackich małych miast i miasteczek, a także wsi ${ }^{23}$. Zasady sterowania rozwojem gospodarczym opartym na obszarach uprzywilejowanych jest regulowany prawnie głównie w zakresie możliwych różnego rodzaju ulg ${ }^{24}$. Samorządy natomiast są zobowiązane do przygotowania terenów i wyposażenia ich w zakresie pełnej infrastruktury technicznej i transportowej.

Powstające specjalne strefy ekonomiczne w Polsce sytuowane są nie tylko w dużych i średnich miastach, ale także w małych miasteczkach (tab. 1.) Wyznaczane tereny dla aktywności gospodarczej jako tereny uprzywilejowane mogą wpływać z jednej strony na poprawę wyglądu estetycznego spowodowaną wznoszeniem nowoczesnych, dobrze zaprojektowanych i starannie wykonanych budynków o charakterze architektury kosmopolitycznej, z drugiej jednak strony tereny niezainwestowane pozostają jako zaniedbane degradując otoczenie. Obserwuje się rozwój terenów uprzywilejowanych w coraz mniejszych miejscowościach regionu karpackiego oraz ich lokalizację pod dyktando inwestora (Błachut 2013). Dodatkowo przypadkowe sytuowanie wielkoprzestrzennych hal w sąsiedztwie drobnej zabudowy mieszkaniowej powoduje obniżenie atrakcyjności przestrzennej całej miejscowości lub jej znaczącego fragmentu.

Konsekwencje przestrzenne i estetyczne sytuowania wielkokubaturowych obiektów przemysłowych w obszarach górskich są bardziej widoczne niż w terenach nizinnych, bowiem wynikają z jednoczesnej i wielopłaszczyznowej możliwości percepcji każdej inwestycji w tym terenie. Należy jednocześnie wziąć pod uwagę fakt, że w wielu miejscowościach tereny przemysłowe nie są usytuowane w sposób ciągły, lecz występują w kilku oddzielnych kompleksach. Często dzielą je pola uprawne lub fragmenty zabudowy ${ }^{25}$. Jednocześnie w polskich terenach górskich dominuje drobna zabudowa mieszkalna, silnie rozproszona, jej bezpośrednie sąsiedztwo z wielkokubaturowymi halami przemysłowymi deprecjonuje ład przestrzenny w tych miejscowościach (Błachut 2013). Tereny uprzywilejowane są stale powiększane, tak że czasami ich powierzchnia wielokrotnie przekracza teren zainwestowania miejscowości ${ }^{26}$. Wyznaczone SSE czy SAG są zagospoda-

${ }^{23}$ Zjawisku temu sprzyja ostatnio wprowadzona możliwość lokowania takich stref na terenach prywatnych.

${ }^{24}$ Początkowym założeniem ustawodawcy miało to być narzędzie istotne w planowaniu rozwoju regionalnego. Kolejne zmiany i aktualizacje Ustawy były przyczyną, że obecnie w Polsce występuje ponad 150 podstref, w kilkuset miejscowościach, w licznych lokalizacjach.

${ }^{25}$ Takie strefy są obecnie wyznaczane np. w Dobczycach i Gdowie.

${ }^{26}$ Sytuacja taka występuje w położonych już co prawda w dolinie Wisły Niepołomicach, w których powierzchnia strefy wynosi 500 ha i w Zatorze, gdzie w latach 2008-2012 
rowywane fragmentarycznie, w sposób punktowy ${ }^{27}$. Stąd część terenów sąsiadujących z wypielęgnowanymi trawnikami zagospodarowanych działek stanowią opuszczone, zarośnięte nieużytki, co dodatkowo obniża jakość tych przestrzeni. Jednocześnie władze samorządu muszą zagospodarować i uzbroić cały wyznaczony teren. Wśród korzystnych przykładów takiej działalności można wymienić $\mathrm{np}$. Myślenice ze zrealizowanym, zgodnie z planami zagospodarowania przestrzennego parkiem przemysłowo-technologicznym w mieście oraz strefą inwestycyjną w Jaworniku, czy Jedlicze z podobną strefą przemysłową. Nadmierne powierzchnie terenów uprzywilejowanych i długie ich zagospodarowywanie obserwowane w coraz większej ilości miasteczek może zagrażać zrównoważonemu ich rozwojowi.

Powstające współcześnie zespoły zabudowy mieszkaniowej wielorodzinnej realizowane są w konwencji postmodernistycznej, często projektowane jako zamknięte kwartały, nierzadko dodatkowo ogrodzone murem, wydzielone z przestrzeni miejskiej. Podobnie wydzielane są zespoły zabudowy jednorodzinnej realizowane najczęściej w formie pasm zabudowy szeregowej, obcej tradycji małych miast karpackich.

Architektoniczny wystrój tej zabudowy czasami nawiązuje do form tradycji lokalnej, ale nie często. Już sama forma rozwiązania układu urbanistycznego, wielkość założenia są odmienne od istniejących w mieście. Czasami zespoły te przylegają bezpośrednio do osiedli z czasów socjalistycznych lub rozproszonej zabudowy jednorodzinnej. Ich realizacja ma poprawić lub przesłonić stan istniejący, jednak wielokrotnie działania te pogłębiają nieład przestrzenny. Tego typu rozwiązania są obserwowane np. w Rabce, Mogilanach, Szczawnicy. Mieszkańcy tych obszarów najczęściej zatrudnieni są na zewnątrz lub jako kadra menadżerska i techniczna w nowo kreowanych obszarach przemysłowych, nie integrują się z miejscową ludnością, co może w przyszłości prowadzić do konfliktów.

Podnosząc poziom obsługi mieszkańców i dla zwiększenia zatrudnienia w gminie lub miasteczku, wznoszone są sklepy wielkopowierzchniowe różnych firm polskich i zagranicznych. Najbardziej ekspansywna wydaje się być sieć Biedronka, Carrefour i Tesco, które niejednokrotnie wznoszą swoje obiekty w tych samych miejscowościach na sąsiadujących działkach ${ }^{29}$. Czasami są to lokalizacje peryferyjne w stosunku do centrum miejscowości, jak np. w Łącku - pawilony

oddano powierzchnię 40 ha dla działalności gospodarczej, ale przewiduje się powiększenie tych terenów do 100 ha.

${ }^{27} \mathrm{~W}$ Niepołomicach z 500 ha zostało zagospodarowane jedynie 200 ha. Podobne sytuacje o mniejszej skali występują w SAG Wojnicz, SAC-SSE Zator, SSE Zagórz, Zasław $i$ inne. Z kolei w SAG Sucha Beskidzka przygotowano 12 ha, lecz obecnie jest mniej chętnych do inwestowania niż kilka lat temu, gdy projektowano to miejsce.

${ }^{29}$ Taka sytuacja jest np. w Łącku, Mszanie Dolnej, Suchej Beskidzkiej, Dukli, Brzozowie, Lesku, Makowie Podhalańskim, Tuchowie. 
Zwiększenie liczby lokalizacji SSE i SAG ${ }^{28}$ w miastach małych i średnich położonych w Karpatach w latach 2007-2015

\begin{tabular}{|c|c|c|}
\hline \multicolumn{2}{|c|}{ Nazwa miasta } & \multirow{2}{*}{$\begin{array}{l}\text { Nazwa Specjalnej } \\
\text { Strefy Ekonomicznej }\end{array}$} \\
\hline 2007 & 2015 & \\
\hline $\begin{array}{l}\text { Jasło } \\
\text { Przemyśl }\end{array}$ & $\begin{array}{l}\text { Jasło } \\
\text { Jedlicze } \\
\text { Przemyśl } \\
\text { Rymanów }\end{array}$ & $\begin{array}{l}\text { Tarnobrzeska SSE } \\
\text { Europark Wisła-San }\end{array}$ \\
\hline $\begin{array}{l}\text { Gorlice } \\
\text { Sanok - obszar przemysłowy }\end{array}$ & $\begin{array}{l}\text { Gorlice } \\
\text { Krosno } \\
\text { Sanok - obszar przemysłowy } \\
\text { Zagórz } \\
\text { Zasław }\end{array}$ & $\begin{array}{l}\text { Mielecka SSE } \\
\text { Europark }\end{array}$ \\
\hline- & $\begin{array}{l}\text { Bochnia } \\
\text { Czorsztyn } \\
\text { Dobczyce } \\
\text { Gdów } \\
\text { Krosno } \\
\text { Limanowa } \\
\text { Myślenice-Jawornik - strefa } \\
\quad \text { inwestycyjna } \\
\text { Niepołomice } \\
\text { Nowy Sącz } \\
\text { Nowy Targ } \\
\text { Pcim - strefa przemysłowa } \\
\text { Siepraw - klaster } \\
\text { Sucha Beskidzka } \\
\text { Sułkowice - klaster } \\
\text { Szczurowa } \\
\text { Tuchów } \\
\text { Wojnicz - strefa inwestycyjna } \\
\text { Zakliczyn } \\
\text { Zator }\end{array}$ & $\begin{array}{l}\text { Krakowski Park } \\
\text { Technologiczny }\end{array}$ \\
\hline- & Myślenice & Katowicka SSE \\
\hline
\end{tabular}

Źródło: opracowanie własne.

28 Specjalne Strefy Ekonomiczne (SSE) to „wyodrębniona, zgodnie z przepisami ustawy, niezamieszkała część terytorium Rzeczypospolitej Polskiej, na której terenie może być prowadzona działalność gospodarcza na zasadach określonych ustawą”, które zaczęto powoływać od 1994 roku początkowo na 20 lat, a w wyniku nowelizacji, czas ich funkcjonowania przedłużono ostatecznie do roku 2026. Strefy aktywności gospodarczej (SAG) to „wydzielone i przygotowane do inwestycji obszary odpowiadające zapotrzebowaniu potencjalnych inwestorów, tworzone najczęściej przez samorządy lokalne" na gruntach gminnych, a ostatnio także na prywatnych, Ustawa z dnia 20.10.1994 roku o specjalnych strefach ekonomicznych (Dz.U., 2007, nr 42, poz. 274 z późn. zm.) oraz J. Stanienda (2011). 
Biedronka i Tesco czy Biedronka w Mszanie Dolnej, czasami kreowane są nowe ośrodki usługowe w centrum miasta, zajmujące rozległe powierzchnie dawnych dworców autobusowych, jak np. Galeria w Mszanie Dolnej - Rossmann, Biedronka i Tesco lub Galeria Dekada w Myślenicach. Niekiedy centra handlowe zajmują odrestaurowane dawne obiekty przemysłowe, np. Stara Cegielnia w Myślenicach lub dawne pawilony osiedlowe, jak w Suchej Beskidzkiej - Tesco.

Nowymi funkcjami, które znacznie rozwinięto w ostatnich latach na obszarze karpackim, nie tylko w miastach średniej wielkości, ale i w małych jest szkolnictwo wyższe i średnie. Liczne szkoły maturalne pojawiają się nawet we wsiach regionu $^{30}$, a szkoły wyższe spotykane są nie tylko w Cieszynie, Jaśle i Sanoku, ale także w Suchej Beskidzkiej i Limanowej. W związku z rozwojem szkolnictwa w ostatnich latach w wielu małych miastach, zagospodarowano nowe duże tereny do funkcji sportowej w formie otwartych boisk, tzw. orlików i hal sportowych, jak np. w Sułkowicach, Łącku i Grybowie.

\subsection{WNIOSKI}

Obserwowane od II połowy XIX wieku przekształcenia struktury przestrzeni małych i średnich miast karpackich przede wszystkim były skutkiem aktywizacji gospodarczej. Pierwotne zmiany miały istotny wpływ na rozplanowanie miasta i zmianę kierunku jego urbanizacji. Obecnie tereny te w wielu przypadkach ani nie są zintegrowane $\mathrm{z}$ miasteczkiem, ani w pełni zagospodarowane i urządzone, choć z nim związane.

Zmiany wprowadzone w II połowie XX wieku są stale rozpoznawalnym dysonansem estetyczno-krajobrazowym. Zespoły osiedli wielorodzinnych złożone z typowych bloków pięciokondygnacyjnych nie uległy przekształceniom. W większym stopniu transformacji podlegają tereny składowe i poprzemysłowe, które przejęły władze samorządowe. Zagospodarowywane są one czasami na cele sportowe i rekreacyjne.

Wprowadzane w ostatnich latach zespoły mieszkalnictwa stałego, jednoi wielorodzinnego wyznaczane są zarówno w ośrodkach położonych w obszarze metropolitalnym, jak i w miejscowościach tradycyjnie wypoczynkowych i uzdrowiskach. Nowo kreowane założenie mieszkaniowe zajmują coraz większe tereny,

${ }^{30} \mathrm{Na}$ przykład w Łącku liczącym 2875 mieszkańców znajdują się: Liceum Ogólnokształcące oraz Zespół Szkół im. św. Kingi z Technikami Budowlanym, Ekonomicznym oraz Żywienia i Gospodarstwa Domowego; z kolei w Grybowie o populacji 6261 mieszkańców są: Liceum Ogólnokształcące im. A. Grottgera, Zespół Szkół Zawodowych oraz Niepubliczne Liceum Ogólnokształcące dla Dorosłych; w Bieczu o liczbie ludności 4728 funkcjonują: Liceum Ogólnokształcące im. S. Wyspiańskiego, Technikum, Zasadnicza Szkoła Zawodowa i Szkoła Policealna; zaś w Nowym Wiśniczu o liczbie ludności 2763 znajdują się: Centrum Kształcenia Ustawicznego, Liceum Plastyczne im. J. Matejki (za: Panorama Firm - Szkolnictwo ponadgimnazjalne). 
jakkolwiek budynki mają niższe gabaryty niż te powstałe 40 lat temu, są one jednak obce estetyce tradycyjnej zarówno w formie rozplanowania urbanistycznego, jak i w wyrazie artystycznym rozwiązań architektonicznych.

Tereny usług handlu pojawiają się w małych miasteczkach w formie hal wielkoprzestrzennych zarówno w zwartej zabudowie miasteczek, jak i w lokalizacjach peryferyjnych, tworząc nowe ośrodki aktywności społecznej, co powoduje rozciąganie założenia małomiasteczkowego wzdłuż tras komunikacyjnych.

Z kolei tereny uprzywilejowane, głównie typu greenfield zajmują powierzchnie porównywalne z obszarem zainwestowania tradycyjnego miasteczka. Wyznaczane są one zarówno w sąsiedztwie miejscowości położonych w obszarze metropolitalnym, jak i w tych atrakcyjnych turystycznie. Punktowe zabudowywanie takich terenów powoduje permanentne ich niezagospodarowanie. Formy obiektów i wspomniany sposób zagospodarowania terenu wpływa na zwiększenie chaosu przestrzennego. Wielkoprzestrzenne hale przemysłowe i handlowo-usługowe o niskim estetycznie wyrazie plastycznym degradują przestrzenie małomiasteczkowe i otaczający je krajobraz. Dodatkowo atrakcyjność lokalizacyjna terenów uprzywilejowanych może okazać się krótkotrwała, a nakłady poniesione przez samorząd na przygotowanie tych terenów w zakresie infrastruktury duże. Równocześnie stale obserwuje się brak zagospodarowania wszystkich istniejących już terenów poprzemysłowych, stąd obawy o podobną sytuację odnośnie nowo wyznaczonych przestrzeni.

W wielu krajach europejskich małe miasteczka stanowią dobry przykład zrównoważonego rozwoju struktur miejskich, stanowiąc pożądane miejsce zamieszkania dla artystów, architektów, naukowców, menadżerów. Wydaje się, że dzisiaj w Polsce niektóre z tych ośrodków w coraz mniejszym stopniu spełniają takie wymogi.

\section{LITERATURA}

Adamczewska-Wejchert H., 1977, Elementy struktury przestrzennej matych $i$ średnich miast polskich, [w:] praca zbiorowa, Przeszłość a jutro miasta, PWN, Warszawa.

Adamczewska-Wejchert H., Wejchert K., 1985, Mate miasta, Warszawa.

Bagiński E., 1998, Małe miasta w strukturze sieci osiedleńczej Polski, Politechnika Wroclawska, Wrocław.

Bartkowicz B., 1999, Wybrane zagadnienia z dziedziny architektury i urbanistyki. Problemy matych miast Polski poludniowej i ich aktualność, Wydawnictwo Politechniki Krakowskiej, Kraków.

Błachut J., 2013, Wplyw specjalnych stref ekonomicznych na strukturę miasta średniej wielkości. Wybrane przykłady z obszaru Polski Poludniowej, Praca doktorska wykonana pod kierunkiem prof. dr hab. inż. arch. Elżbiety Węcławowicz-Bilskiej.

Drexler I., 1921, Odbudowa miast i wsi na ziemi naszej, Wydawnictwo Zakładu im. Ossolinskich, Lwów. 
Dziewoński K., 1957, Rozwój problematyki badań geograficznych nad małymi miastami. Studia geograficzne nad aktywizacja matych miast, „Prace Geograficzne”, 9, PWN, Warszawa.

Gałęzowski J. (red.), 1916, Odbudowa polskiego miasteczka: projekty domów opracowane przez grono architektów polskich, Kraków.

Gzell S., 1981, Miasteczko w krajobrazie podgórskim, PWN, Warszawa-Łodź.

Gzell S., 1987, Fenomen małomiejskości, Politechnika Warszawska, Warszawa.

Heffner K., Marszał T., 2005, Wprowadzenie, [w:] Heffner K., Marszał T. (red.), Problemy rozwoju miast w wymiarze lokalnym i regionalnym, „Biuletyn KPZK”, 220, Warszawa, s. 5-6.

Kwiatek-Sołtys A., 2004, Małe miasta województwa małopolskiego w okresie transformacji systemowej, Wydawnictwo Naukowe Akademii Pedagogicznej w Krakowie, Kraków.

Marszał T. (red.), 2009a, Funkcja przemysłowa małych miast, Wydawnictwo Uniwersytetu Łódzkiego, Łódź.

Marszał T. (red.), 2009b, Struktura funkcjonalna małych miast, Wydawnictwo Uniwersytetu Łódzkiego, Łódź.

Moczulski M., 2007, Parowozem do Kęt, „Świat Kolei”, 7, Emi-Press, Łódź.

Pieńkowska H., 1971, Prace konserwatorskie na terenie województwa krakowskiego w latach 1958-1968, cz. I: Zabytki architektury, „Ochrona Zabytków”, 24/1 (92), s. 61-76.

Stanienda J., 2011, Determinanty rozwoju stref aktywności gospodarczej, „Zeszyty Naukowe MWSE w Tarnowie", 17, s. 255-265.

Warszyńska J. (red.), 1995, Karpaty Polskie. Przyroda, człowiek i jego działalność, Wydawnictwo Uniwersytetu Jagiellońskiego, Kraków.

Wejchert K., 1947, Miasteczko polskie jako zagadnienie urbanistyczne, Wydawnictwo Ministerstwa Odbudowy, nr 8, Warszawa.

Węcławowicz-Bilska E., 1990, Historyczne założenia zdrojowisk w kształtowaniu wspótczesnych ośrodków balneologicznych w Polsce, Wydawnictwo Politechniki Krakowskiej, Kraków.

Zaniewska H., 2014, Rozmieszczenie, przestrzeń $i$ cechy małych miast na przełomie XX i XXI wieku, „Problemy Rozwoju Miast”, 11 (3).

\begin{abstract}
The Carpathian region is characterized by the accumulation of numerous natural and cultural resources protected by law. The traditional function of these areas was agriculture and herding. Natural resources are the basis for development of the therapeutic spa function.

Construction of railway lines in the second half of the nineteenth century resulted in more dynamic economic development based on industry and tourism. Subsequent actions have contributed to increasing the urbanized area, often in a piecemeal manner, without due attention to spatial order.

The consequences of these decisions for landscape, aesthetics, society and economy can have a lasting impact on spatial order and the possibility of sustainable development.
\end{abstract}

\title{
Keywords
}

Carpathian region, small towns, economic development. 